RESENHA

Bookreview

\title{
THE CARTOGRAPHIC STATE MAPS, TERRITORY, AND THE ORIGINS OF SOVEREIGNTY ${ }^{1}$
}

Thiago Correa Malafaia ${ }^{2}$

Power, sovereignty, the International. Theses are all dear concepts to International Relations. Much has been theorized on these subjects. Anyhow, little attention has been directed as to how the representation of spatial territory, in the form of maps, contributed to the crucial events that were paramount to the shaping of the field. And that is precisely what Branch tries to achieve with his newest book - The Cartographic State: Maps, Territory, and the Origins of Sovereignty - that came out early this year (2014).

The author's argument traverses about how the perception of territory and rule, and thus, power, sovereignty, and the International changed as a consequence of improvements in the map-making technology and how the logics of 'rule', understood as the authority de facto exercised by a particular ruler, king, prince, feudal lord and the like in a particular territory, changed, from an interest in what existed per se in that given region, be it people, productive land, herds of animals, or even entire shires, villages, burgs, and/or cities, to the modern logic of linear boundaries. This brought stark consequences to the "domains"for some reasons. For the sake of concision and in lieu of the limited space I point out only two of the most decisive contributions, what

\footnotetext{
${ }^{1}$ BRANCH, Jordan; The Cartographic State: Maps, Territory, and the Origins of Sovereignty; Cambridge University Press, New York; 2014; 219 p.; ISBN 978-1-107-04096-0.

${ }^{2}$ Mestre em Relações Internacionais pela Pontifícia Universidade Católica de Minas Gerais. Doutorando pela Pontifícia Universidade Católica de Minas Gerais. Email: thiagomalafaia@ hotmail.com.
} 


\section{Conjuntura Austral}

does not mean that other impacts were non-existent: on the one hand, it changed how different "domains"dealt with each other for the shift brought about a new modus operandi for treaty-making; on the other hand, it also changed how a given "domain"saw its own territory and thus helped it realize the best strategies to follow.

According to Branch, so the argument goes, the reorientation as to how one saw one's own "domains"contributed to the shaping of the modern state system. What is most striking, however, about the research conducted by the author is his use of ideas and norms, focusing on how these elements can effectively explain the effects generated by technological improvements in map-making, profoundly impacting upon the conduction of politics. Indeed, as shown by the book, these shifts were far from straightforward and instantaneous. As a matter of fact, the whole process was one of staggering complexity. An intricateness seldom envisaged and covered by International Relations researches about the coming into being of the modern state. I top this discussion off with one argument of the author about how even the conduct of wars changed: the political goals of territorial expansion, or defense, for that matter, were deeply modified so as to fit the new way of viewing the space, now linearly defined, as opposed to a conglomerate of jurisdictions, en vogue up until the change and dissemination of new cartography technology.

The book struggles to answer one stupefying question: "why is today's world map filled with territorial states separated by linear boundaries?'(Branch, 2014:1). Accomplishing, though, the task with flying colors, the author really makes one think about the incommensurable contribution of cartography in the shaping of International Relations as they are known today.

As for the research method, the author utilized the systematic study of the changes in ideational frameworks, so as to thoroughly document shifts, both in mapmaking technology and ideational, and try and trace a causal relationship back to the observable implications of these events in the form of shifts in politics making. In order to do this Branch worked extensively with narrative analysis and process-tracing.

As a whole, the book is comprised of eight chapters. In the last of them the author discusses the "cartographic"state nowadays. All in all, it is an excellent read, 


\section{Conjuntura Austral}

specially for those who are researching subjects such as sovereignty or even the evolution of treaty-making in retrospect and over the centuries. In addition, the book might also prove useful for those who are researching the dynamics of border formation via ideational lenses, in a wider context - a discussion that remains opaque in the discipline of International Relations.

Resenha recebida dia 21 de abril de 2014. Aprovado em 30 de abril de 2014. 